\title{
Predictors of behavioral problems in adolescents: family, personal and demographic variables
}

\author{
Josiane Rosa Campos ${ }^{1}$ \\ Alessandra Turini Bolsoni Silva ${ }^{2}$ \\ Marta Regina Gonçalves Correia Zanini ${ }^{3}$ \\ Sonia Regina Loureiro ${ }^{4}$ \\ ${ }^{1} I N A C$ - Instituto de Análise do Comportamento de Ribeirão Preto, Ribeirão Preto, SP \\ ${ }^{2}$ Universidade Estadual Paulista Júlio de Mesquita Filho, São Paulo, SP \\ ${ }^{3}$ Centro Universitário das Faculdades Associadas de Ensino - UNIFAE, São João da Boa Vista, MG \\ ${ }^{4}$ Faculdade de Medicina de Ribeirão Preto/ USP, Ribeirão Preto, SP
}

\begin{abstract}
This study aimed to correlate, compare and identify the family, personal and demographic variables that may predict behavioral problems in adolescents. A total of 300 adolescents participated, 230 with behavioral problems (177 girls and 53 boys; $M=14.00$ years; $S D=1.24$ ) and 70 without (47 girls and 23 boys; $M=14.09$ years; $S D=1.33$ ). Data was collected through questionnaires and inventories completed by adolescents and analyzed using Pearson's correlation, Student's t-tests and multiple binary logistic regression. Results showed low self-control as a risk factor and social skills and low frequency of physical abuse and maternal neglect as protection factors. The model evaluated had a reasonable predictive power $(79.9 \%$, specificity $93.9 \%$ and sensitivity $34.3 \%$ ). The findings contribute to the prevention of behavioral problems in adolescents.

Keywords: adolescents; behavioral problems; risk factors; protection
\end{abstract}

Preditores de problemas comportamentais em adolescentes: variáveis familiares, pessoais e demográficas

\begin{abstract}
Resumo
O estudo teve por objetivo correlacionar, comparar e identificar as variáveis familiares, pessoais e demográficas que podem ser preditivas para problemas de comportamento de adolescentes. Participaram 300 adolescentes, sendo 70 sem problemas de comportamentos (47 meninas e 23 meninos; $M=14,09$ anos e $D P=1,33$ ) e 230 com problemas de comportamento (177 meninas e 53 meninos; $M=14,00$ anos; $D P=1,24)$. Os dados foram coletados via questionários e inventários aplicados com os adolescentes e foram analisados via correlação de Pearson, teste $t$ de Student, regressão logística múltipla binária. Os resultados apontaram que baixo autocontrole foi fator de risco e desenvoltura social, baixa frequência de abuso físico e negligência materna foram fatores de proteção. O modelo avaliado apresentou razoável poder preditivo (79,9\%, sendo a especificidade foi de $93,9 \%$ e a sensibilidade de $34,3 \%$ ). Os achados contribuem para a prevenção de problemas de comportamento em adolescentes. Palavras-chave: adolescents, problemas de comportamento, fatores de risco, proteção
\end{abstract}

Predictores de problemas conductuales en adolescentes: variables familiares, personales y demográficas

\section{Resumen}

El presente estudio tuvo como objetivo correlacionar, comparar e identificar las variables familiares, personales y demográficas que pueden ser predictores de problemas de comportamiento en adolescentes. Participaron 300 adolescentes, 70 sin problemas de comportamiento (47 niñas y 23 niños; $M=14,09$ años; $D . P=1,33$ ) y 230 con problemas de comportamiento (177 niñas y 53 niños; $M=14,00$ años; $D \cdot P=1,24)$. Los datos fueron recogidos a través de cuestionarios e inventarios aplicados a los adolescentes, y se analizaron utilizando correlación de Pearson, Test $t$ de Student, y regresión logística múltiple binaria. Los resultados indicaron que el bajo autocontrol fue un factor de riesgo, mientras que el desarrollo social, la baja frecuencia de abuso físico y negligencia materna fueron factores de protección. El modelo evaluado presentó un poder predictor razonable $(79,9 \%$, siendo la especificidad de $93,9 \%$ y la sensibilidad de 34,3). Los resultados contribuyen en la prevención de problemas de comportamiento en adolescentes. Palabras clave: adolescentes; problemas de comportamiento; factores de riesgo; protección

Behavioral problems in adolescents are a public health concern, since they are common and constitute the basis for the development of other problems of the same nature in adulthood (Perera, 2013). According to data from the World Health Organization (WHO, 2012), at least $20 \%$ of the adolescent population could be affected by these problems. Among the most prevalent include anxiety and depression, considered to be internalizing behavioral problems, which also include shyness, Withdrawn and somatic complaints; as well as externalizing behavioral problems, considered to be antisocial behaviors such as breaking social rules and aggressiveness (Bordin et al., 2013). 
Considering the characteristics of the developmental period of adolescence and the behavioral problems theme, the present study focused on the following variables that were identified as risk factors in some studies: (a) family - parenting practices (Milkman \& Wanderg, 2012); (b) personal - social skills, social competence (Del Prette, Rocha, Silvares, \& Del Prette, 2012); academic performance and substance use (Milkman \& Wanderg, 2012); (c) demographic - age, socioeconomic status and gender (Rocha, 2012).

According to Gomide (2014), parenting practices involve the behaviors of the parents associated with affection, the establishment of limits and rules, the supervision of activities and the monitoring of the social/moral and academic behavior of their children. Some studies have highlighted that positive maternal practices are related to lower incidences of behavioral problems and negative parenting practices are positively correlated with behavioral problems (Sabbag, 2010; Salvo, 2010).

Evaluating a predictive model, Toni and Silvares (2013) identified that the absence of positive monitoring and the presence of negative monitoring and paternal physical abuse were predictors of behavioral problems in adolescents. Other studies have also identified physical punishment as a predictor of behavioral problems; (Cassandra, 2010; Ma, Han, Grogan-Kaylorb, Delva, \& Castillo, 2012). The presence of less support and low maternal monitoring were identified as predictors of behavioral problems in the children (Aalsma, Liu, \& Wiehe, 2011). Parental neglect was also identified as a predictor of behavioral problems in adolescents (Cassandra, 2010; Mills, Scott, Alati, O'Callaghan, Najman, \& Strathearn, 2013). Gomide (2014) identified that positive moral behavior and monitoring (positive parenting practices) were associated with pro-social behaviors, while negative parenting practices (relaxed discipline, inconsistent punishment, physical abuse and neglect) were associated with the development of behavioral problems in adolescents.

As personal variables, social skills are classes of social behaviors present in the individual's repertoire, which are more likely to produce reinforcing consequences for the individual and others and are required for socially competent performance (Del Prette \& Del Prette, 2012). Social competence, however, requires the articulation of various social skills in order to achieve goals, maintain/improve self-esteem, maintain/acquire human rights, and balance reinforcers among people (Del Prette \& Del Prette, 2001). In the view of
Achenbach and Rescorla (2001), social competence is evaluated by the adolescents' engagement in relationships. In the study by Del Prette et al. (2012), the authors identified negative correlations between social skills of civility in the frequency indicator and Depressed/ Withdrawn, social and attention problems, and negative correlations between assertiveness and attention problems. Additionally, they identified positive correlations between difficulty in self-control, social resourcefulness and anxious/depressed; social problems and difficulty of empathy; attention problems and civility; and breaking of rules and difficulty in self-control for adolescents with behavioral problems. These results were similar to those of Sabbag (2010).

In a comparative study between adolescents with and without indicators of depression (internalizing), Campos (2014) identified that the group with indicators of depression presented lower frequencies in most of the social skill classes and high response costs to emit them. Part of the results of the study by Durlak, Weissberg, and Pachan (2010) found that when developing social skills, behavioral problems reduced significantly.

Campos, Del Prette and Del Prette (2014) reported that good self-control and empathy can be protective factors and difficulty in civility may be a risk factor for the development of indicators of depression that ultimately indicate the presence of internalizing behavior problems. Sabbag \& Bolsoni-Silva (2015) also found that adolescents with no behavioral problems had more social skills and greater repertoires of social skills. Analyzing these data it can be observed that the studies highlighted that there are negative associations between social competences, social skills and behavior problems, demonstrating the relevance of including these variables in studies that seek a better comprehension of adolescent health.

Another personal variable of the adolescent considered a risk factor, low academic performance, was identified in the study of McLeod, Uemura, and Rohrman, (2012) as being associated with externalizing behavior problems. On the other hand, in order to identify relationships between internalizing, externalizing and academic performance problems of adolescents, a study by Hossain (2013) identified significant negative correlations between these variables. Sabbag and Bolsoni-Silva (2015) found that adolescents with no behavioral problems presented better academic performance. As can be seen, although there is no consensus, the literature indicates consistent associations between behavioral problems and low academic performance. 
Considering substance use, a personal variable, studies by Colder et al. (2012) and Goodman (2010) highlighted that externalizing behavior problems and the co-occurrence with internalizing problems in adolescents were associated with alcohol and other substances (cannabis and alcohol), while "pure" internalizing problems did not present this association. However, the study by Kirkcaldy, Siefen, Surall and Bischoff (2004) identified that anxiety and depression were specifically predictors of marijuana use. Therefore, behavioral problems have been shown to be associated with the use of alcohol and other drugs.

Concerning demographic variables, MillsKoonce et al. (2016) and Rocha (2012) identified that economic disadvantage increased the probability of emergence and/or maintenance of responses considered to be behavioral problems. However, the study by Havas, Bosma, Spreeuwenberg and Feron (2010) indicated that socioeconomic status was not associated with behavioral problems. The age of the adolescent also has an association with behavioral problems, with older individuals tending to present more behavioral problems than younger individuals (Rocha, 2012; Salvo, 2010). Considering that these demographic variables have shown associations with adolescent behavioral problems, their inclusion in the present study is justified, aiming to clarify their role in the behavior problems of adolescents.

The analysis of these studies, in general, shows that they identified statistically significant associations between adolescent behavioral problems and variables, such as academic performance, the use of alcohol and other substances, demographic variables, parenting practices, social competences and social skills. However, two considerations are necessary. The first is that in the set of correlational, comparative and predictive studies, the studies identified used two or three variables in the analyses. Although this is important for a first step, behavioral problems are complex and multidetermined (Milkman \& Wanderg, 2012), which presupposes that, for a better comprehension of them, it is necessary to include multiple variables in the analysis, this being a gap addressed by the present study.

The second consideration addresses the identification of the predictive value of a model, since, in addition to correlating and comparing the variables, it is necessary that they be evaluated together. The identification of critical variables provides a more refined look at the phenomenon and indicates ways to design prevention and treatment programs. The present study intended to address these gaps, aiming at correlating, comparing and identifying family, personal and demographic variables that can be predictive of the behavioral problems of adolescents. The aim of this study was to identify, from self-reported measures applied with adolescents, which of the possible independent variables: parenting practices (family), social skills, social competence, academic performance, substance use (personal), age, socioeconomic status, gender (demographic) can be predictive of behavioral problems, aiming to estimate the predictive value of an identified model.

\section{Method}

The study followed a cross-sectional, comparative and analytical design (Anzano, Rubio, \& Sánchez, 2004).

\section{Participants}

A convenience sample of 300 adolescents of both sexes (25.3\% male, $74.7 \%$ female) was identified in 13 public schools in two cities of the state of São Paulo, 70 with no behavioral problems (nonclinical group) and 230 with behavior problems (clinical group). The selection of the groups with and without behavioral problems was based on the Youth Self-Report (YSR) (Achenbach \& Rescorla, 2001), with the presence of scores corresponding to clinical or borderline classifications in at least one of the scales of internalizing, externalizing or total problems adopted as the criteria for considering the subject clinical. In order to be considered nonclinical the absence of a score corresponding to the clinical or borderline classifications in any of the internalizing, externalizing or total problem scales was considered necessary. The inclusion criteria of the sample were to be between 12 and 16 years of age and to respond correctly to at least $90 \%$ of the items of all the instruments.

Table 1 describes the demographic characteristics of the adolescents, considering both groups.

A chi-squared analysis showed that the clinical and nonclinical samples did not present statistically significant differences. The samples are equivalent for: age: $\left(\chi^{2}=1.907 ; p=0.753\right)$; gender $\left(\chi^{2}=2.378\right.$; $p$ $=0.123)$; and education $\left(\chi^{2}=4.105 ; p=0.663\right)$. Student's t-test for independent samples showed that the socioeconomic level $(t=7.04 ; p=0.482)$ also did not differentiate the groups. 
Table 1.

Demographic Characteristics of the Nonclinical and Clinical Groups of Adolescents

\begin{tabular}{|c|c|c|c|c|c|}
\hline \multirow[b]{2}{*}{ Variables } & & \multicolumn{2}{|c|}{ Nonclinical Group } & \multicolumn{2}{|c|}{ Clinical Group } \\
\hline & & $\begin{array}{l}\text { Absolute } \\
\text { Frequency }\end{array}$ & $\begin{array}{c}\text { Relative } \\
\text { Frequency } \\
(\%)\end{array}$ & $\begin{array}{l}\text { Absolute } \\
\text { Frequency }\end{array}$ & $\begin{array}{c}\text { Relative } \\
\text { Frequency } \\
(\%)\end{array}$ \\
\hline \multirow{3}{*}{ Gender } & $\mathrm{F}$ & 47 & 67.1 & 177 & 77.0 \\
\hline & M & 23 & 32.9 & 53 & 23.0 \\
\hline & total $n$ & 70 & 100 & 230 & 100 \\
\hline \multirow{6}{*}{ Age } & 12 years & 13 & 18.6 & 37 & 16.1 \\
\hline & 13 years & 10 & 14.3 & 41 & 17.8 \\
\hline & 14 years & 15 & 21.4 & 63 & 27.4 \\
\hline & 15 years & 22 & 31.4 & 63 & 27.4 \\
\hline & 16 years & 10 & 14.3 & 26 & 11.3 \\
\hline & Mean $(S D)$ & $\begin{array}{c}14.09 \text { years } \\
(1.33)\end{array}$ & & $\begin{array}{c}14.00 \text { years } \\
(1.24)\end{array}$ & \\
\hline \multirow{7}{*}{ Education } & $6^{\text {th }}$ year & 6 & 8.6 & 34 & 14.9 \\
\hline & $7^{\text {th }}$ year & 4 & 5.7 & 17 & 7.5 \\
\hline & $8^{\text {th }}$ year & 18 & 25.7 & 63 & 27.6 \\
\hline & $9^{\text {th }}$ year & 5 & 7.1 & 15 & 6.6 \\
\hline & $1^{\text {st }} \mathrm{HSE}$ & 19 & 27.1 & 67 & 29.6 \\
\hline & $2^{\text {nd }} \mathrm{HSE}$ & 15 & 21.4 & 32 & 14.0 \\
\hline & A1 & - & - & 1 & 0.4 \\
\hline \multirow{6}{*}{ Socioeconomic Level } & A2 & 5 & 7.1 & 13 & 5.7 \\
\hline & B1 & 18 & 25.7 & 57 & 24.8 \\
\hline & B2 & 29 & 41.4 & 101 & 43.9 \\
\hline & C1 & 13 & 18.6 & 44 & 19.1 \\
\hline & C2 & 4 & 5.7 & 14 & 6.1 \\
\hline & $\mathrm{D}$ & 1 & 1.4 & & \\
\hline
\end{tabular}

Note. $n$ - sample size; (\%) percentage; (SD) standard deviation; HSE - High School Education

\section{Instruments}

The Youth Self-Report-YSR (Achenbach \& Rescorla, 2001) is a self-administered instrument, directed toward adolescents aged 11 to 18 years, which aims to evaluate global behaviors and emotional/behavioral difficulties, distributed in two parts: (a) the first, the competences scale, is designed to identify the sports practices, relationships with friends, extracurricular activities and academic performance of the adolescent; (b) the second, the scale of emotional and behavioral problems, has 112 items corresponding to eight syndrome scales, these being: Anxious/Depressed, Withdrawn/Depressed, Somatic Complaints, Social
Problems, Attention Problems, Thought Problems, Delinquent Behavior, and Aggressive Behavior. The sums of the scores in the behavioral problems scales configure scales of internalization, externalization, and total scale of emotional and behavioral problems. It was translated and validated in Brazil by Rocha (2012). For the competence scale, the alpha obtained for the Total Scale in the sample of the study was acceptable (0.61). The validation presented results that indicate the relevance of the factorial model of the instrument for the Brazilian population (RMSEA $=0.032$ ), Cronbach's alpha coefficient with values very similar to the original values were found by Rescorla et al. (2007), 
with a mean alpha of 0.94 for the scales of emotional and behavioral problems; 0.86 for the internalization and externalization scales; 0.75 for positive aspects; 0.62-0.82 for the empirically-based syndromes and 0.50.75 for the DSM-IV guided scales. The YSR was used to compose the sample.

The Social Skills Inventory for Adolescents (Inventário de Habilidades Sociais para Adolescentes - IHSA-DEL PRETTE, 2009) is a self-report instrument composed of 38 items, directed towards adolescents aged 12 to 17 years, proposing to evaluate the social skills repertoire and presenting two indicators: frequency and difficulty, in the subclasses: Empathy, Self-control, Civility, Assertiveness, Affective Approach and Social Resourcefulness. In the validation study of the instrument (Del Prette \& Del Prette, 2009), the instrument's internal consistency indices (Cronbach's alpha coefficient) for the frequency indicators were: Total score $=$ $0.89 ; \mathrm{F} 1=0.82 ; \mathrm{F} 2=0.72 ; \mathrm{F} 3=0.75 ; \mathrm{F} 4=0.67 ; \mathrm{F} 5=$ $0.69 ;$ and $\mathrm{F} 6=0.61$. The consistency values obtained for the difficulty indicator were: Total score $=0.90 ; \mathrm{F} 1$ $=0.86 ; \mathrm{F} 2=0.75 ; \mathrm{F} 3=0.83 ; \mathrm{F} 4=0.72 ; \mathrm{F} 5=0.67 ; \mathrm{F} 6$ $=0.51$ (Del Prette $\&$ Del Prette, 2009). All the variables of this instrument were analyzed.

The Drug Use Screening Inventory (DUSI) (Tarter, 1990) is a questionnaire widely used in epidemiological studies to identify cases of alcohol and other substance abuse in adolescents aged 12 to 19 years. For this study, the Brazilian version of the instrument adapted and validated by De Micheli and Formigoni (2000) was used. As shown in Figure 1, it has 15 self-administered questions related to the use of alcohol and other substances. To detect the risk of substance use, the cut-off point adopted by the instrument is three or more affirmative answers, ranging from 0 to 15 points. No risk for substance use is considered with less than three affirmative answers. The categorical variable to present risk or not was used in the analyses.

The Parenting Styles Inventory (Inventário de Estilos Parentais - IEP) (Gomide, 2014) consists of seven scales that evaluate parenting practices: two considered positive (positive monitoring and moral behavior) and five negative (physical abuse, relaxed discipline, negative monitoring, neglect and inconsistent punishment), totaling 42 questions. It has versions for parents and young people, with the use of the adolescent version in this study, covering their perceptions regarding the maternal parenting practices. The parental style index between the 01-50 percentiles signifies a strong presence of negative practices, which promote behavioral problems. The parental style index between the 55-99 percentiles indicates a strong presence of positive practices, which are preventive of behavioral problems (Gomide, 2014; Sabbag \& Bolsoni Silva, 2013). In the instrument validation study (Gomide, 2014), the internal consistency indices (Cronbach's alpha coefficient) were: Positive monitoring $=0.61$; Moral behavior $=$ 0.70 ; Inconsistent punishment $=0.66$; Neglect $=0.73$; Relaxed discipline $=0.62 ;$ Negative monitoring $=0.47$; and Physical abuse $=0.82$. All the variables of this instrument were evaluated in the present study.

The Criterion Brazil- Criterion of Economic Classification Brazil (CCEB, IBOPE/ABEP, 2014) instrument classifies the socioeconomic level, from the possession of durable consumer goods and other factors, such as the employment of domestic workers. The score obtained distributes the social classes into A1, A2, B1, B2, C1, C2, D and E and also generates an overall score. In the present study, it was completed by the young people and the overall score obtained was used.

\section{Procedures}

Data collection. The participation of the adolescent was conditional upon the presentation of the consent form signed by parents and/or guardians and delivery of the agreement form signed by the adolescent. After obtaining consent from the Research Ethics Committee, from the State Department of Education and from the school principals the data collection was started. The adolescents were informed that the study aimed to identify feelings, behaviors and social interactions with their mothers, as well as health information. The instruments were presented in printed notebooks, in the following order: YSR, IEP, DUSI, IHSA and Criterion Brazil, preceded by specific instructions. When the participants were in doubt, they were instructed to address, individually, the applicator present in the room.

Data analysis. All analyses were performed using the IBM SPSS for Windows, version 22 software. The YSR data were entered and computed, prior to the analyses, in the instrument's software called Assessment Data Manager (ADM). According to the $\mathrm{t}$ scores generated, the program classifies the adolescent as having no problems, being assigned the value in the category equal to 0 (nonclinical group) or having behavior problems, with the value in the category corresponded to 1 (clinical group). The computation and tabulation of the other instruments were carried out according to their standard recommendations. The normality of the data was first checked using the 
Kolmogorov-Smirnov test, which showed that all the variables presented normal distributions.

To perform the correlational analyses between the continuous variable behavior problems of adolescents and the continuous variables of the YSR (social competence, academic performance), of the IHSA (of the six classes of social skills in the indicators of frequency and difficulty), of the IEP, seven parenting practices, and of the demographic variables (age, economic status) Pearson's correlation coefficient was used.

The nonclinical and clinical groups were compared in relation to the continuous variables of the YSR (social competence, academic performance), of the IHSA (of the six social skills classes in the indicators of frequency and difficulty), of the IEP (seven parenting practices), and of the demographic variables (age, economic status). For these analyses Student's t-test for independent samples was applied, considering differences with $p \leq 0.05$ as significant. To measure the effect size in the comparisons, Cohen's d was calculated, which considers the effect as small when $\mathrm{d}$ $\leq 0.2$; medium when $\mathrm{d}$ is between 0.2 and 0.5 ; high when $\mathrm{d}$ is between 0.50 and 1 ; and very high when $\mathrm{d}$ $>1$ (Cohen, 1988, apud Marôco, 2011). The chi-squared test was used to compare the same groups regarding the categorical variables (substance use and gender), also considering the $95 \%$ confidence interval.

Prior to the analyses, multicollinearity diagnoses were performed through binary correlation analyses, considering values of 0.9 as critical and indicators for exclusion, with no variables complying with this assumption. The issue of missing data was addressed through the multiple imputation for missing data method.

In order to perform the predictive analyses, Binary Logistic Regression analysis was used, having the behavioral problems as the dependent variable or predictor, with the clinical group assuming a value of 1 and the nonclinical group a value of 0 . The independent variables or predictors of the model were social skills (six factors in frequency and difficulty indicators), social competence, academic performance, socioeconomic status, age and maternal/caregiver parenting practices (seven practices: two positive and five negative). The gender and risk for substance use variables were considered dummy variables, with a value of 1 being attributed to females and to the condition of risk for drug use. In the final model, only the independent variables with a coefficient of $p \leq 0.05$ were included. The goodness of fit of the adjusted model was assessed using the Hosmer-Lemeshow test.
Subsequently, the Enter method was used to select the predictors.

\section{Ethical issues}

The study was approved by the Ethics Committee of the University, under CAAE: 38705214.4.0000.5398, in compliance with the ethical standards of the National Health Council (Resolution 196/96).

\section{Results}

This section is divided according to the proposed objectives, presenting the correlational, comparative and predictive analyses only for the data that were statistically significant.

The statistically significant negative correlations between the continuous variables investigated and the behavior problems of the adolescents were: Social competence $(r=-0.127 ; p=-0.03)$; Academic performance $(r=-0.152 ; p=0.09)$; General score of social skills frequency $(r=-0.227 ; p \leq 0.001)$; F1-Empathy ( $\mathrm{r}$ $=-0.210 ; \mathrm{p} \leq 0.001) ;$ F2- Self-control $(\mathrm{r}=-0.227 ; \mathrm{p} \leq$ 0.001); F3-Civility $(r=-0.170 ; p=0.003)$; F4-Assertivity $(r=-0.155 ; p=0.007)$; F6- Social resourcefulness $(r$ $=-0.192 ; p \leq 0.001)$; Parenting Styles total score $(r=$ $-0.490 ; p \leq 0.001)$; Positive monitoring $(r=-0.226$; $p$ $\leq 0.001)$ Moral behavior $(r=-0.197$; $p \leq 0.001)$; Physical abuse $(r=-0.293 ; p \leq 0.001)$; Neglect $(r=-0.461 ; p$ $\leq 0.001)$; Negative monitoring $(r=-0.160 ; p=0.005)$; Relaxed discipline $(r=-0.386 ; p \leq 0.001)$; and Inconsistent punishment $(r=-0.365 ; p \leq 0.001)$. These data showed that with higher scores for behavioral problems, the YSR, IHSA and IEP indices were more negative.

The significant positive correlations were: General score of social skills difficulty $(r=0.258 ; p \leq 0.001)$; D1- Empathy $(r=0.295 ; p \leq 0.001)$; D2-Self-control $(r$ $=0.337 ; p \leq 0.001)$; D3-Civility $(r=0.289 ; p \leq 0.001)$; D4-Assertivity $(r=0.275 ; p \leq 0.001) ;$ D5-Affective approach $(r=0.252 ; p \leq 0.001)$; and D6 - Social resourcefulness $(r=0.210 ; p \leq 0.001)$. These data show that with higher scores for behavioral problems, to emit social behaviors is more difficult.

Table 2 describes the descriptive and comparative data of the clinical and nonclinical groups in the continuous variables that were statistically significant.

From Table 2, it can be seen that the clinical group presented lower means in the classes of social skills, in the frequency indicators: total score, F1-self-control and F6-social resourcefulness. In the classes of social skills 
Table 2.

Descriptive and Comparative Data of the Clinical and Nonclinical Groups

\begin{tabular}{|c|c|c|c|c|c|c|}
\hline Variables & Scales & Groups & $M$ & $S D$ & $t$ & $d$ \\
\hline \multirow{6}{*}{$\begin{array}{l}\text { Social Skills } \\
\text { Frequency }\end{array}$} & General Score & Clinical & 35.09 & 31.47 & $2.69^{* *}$ & 0.37 \\
\hline & & Nonclinical & 47.81 & 35.44 & & \\
\hline & Self control & Clinical & 38.99 & 33.16 & $3.64^{* * *}$ & 0.49 \\
\hline & & Nonclinical & 55.58 & 34.06 & & \\
\hline & Social Resourcefulness & Clinical & 35.93 & 30.40 & $2.99^{* *}$ & 0.39 \\
\hline & & Nonclinical & 48.74 & 34.17 & & \\
\hline \multirow{12}{*}{$\begin{array}{l}\text { Social Skills } \\
\text { Difficulty }\end{array}$} & General Score & Clinical & 50.06 & 33.46 & $-2.55^{*}$ & -0.35 \\
\hline & & Nonclinical & 37.32 & 37.33 & & \\
\hline & Empathy & Clinical & 57.21 & 31.98 & $-3.04^{* *}$ & -0.40 \\
\hline & & Nonclinical & 43.70 & 34.15 & & \\
\hline & Self control & Clinical & 46.57 & 29.38 & $-4.58^{* * *}$ & -0.63 \\
\hline & & Nonclinical & 28.37 & 28.20 & & \\
\hline & Civility & Clinical & 59.87 & 31.43 & $-3.01^{* *}$ & -0.42 \\
\hline & & Nonclinical & 45.65 & 35.51 & & \\
\hline & Assertiveness & Clinical & 56.39 & 31.78 & $-2.73^{* *}$ & -0.38 \\
\hline & & Nonclinical & 43.60 & 35.00 & & \\
\hline & Affective approach & Clinical & 44.47 & 29.63 & $-2.00^{*}$ & -0.26 \\
\hline & & Nonclinical & 36.25 & 31.65 & & \\
\hline \multirow{12}{*}{$\begin{array}{l}\text { Maternal parenting } \\
\text { practices }\end{array}$} & Positive Monitoring & Clinical & 38.84 & 32.84 & $3.48^{* *}$ & 0.47 \\
\hline & & Nonclinical & 54.49 & 33.07 & & \\
\hline & Moral Behavior & Clinical & 42.58 & 28.41 & $2.41^{*}$ & 0.33 \\
\hline & & Nonclinical & 52.57 & 30.82 & & \\
\hline & Physical Abuse & Clinical & 40.59 & 35.35 & $4.40^{* * *}$ & 0.61 \\
\hline & & Nonclinical & 63.57 & 39.06 & & \\
\hline & Neglect & Clinical & 31.10 & 29.22 & $6.75^{* * *}$ & 0.89 \\
\hline & & Nonclinical & 58.80 & 32.54 & & \\
\hline & Relaxed Discipline & Clinical & 44.52 & 29.69 & $5.70^{* * *}$ & 0.79 \\
\hline & & Nonclinical & 65.66 & 26.30 & & \\
\hline & Inconsistent Punishment & Clinical & 36.71 & 29.29 & $5.10^{* * *}$ & 0.78 \\
\hline & & Nonclinical & 56.80 & 21.19 & & \\
\hline
\end{tabular}

Note: Clinical Group $(n=230)$, Nonclinical Group $(n=70) ; * * x \leq 0.001 ;{ }^{* *} p \leq 0.01 ;{ }^{*} p \leq 0.05 ; d=$ effect size statistic - Cohen's d.

in the indicators of difficulty, the clinical group presented means significantly higher than the nonclinical group in: general score, D1- empathy; D2-self-control; D3-civility and D4-affective approach. The effect size ranged from -0.26 (D4- affective approach) to -0.63 (D2- self-control), and can be considered to be medium in all comparisons except for D2-self-control, in which the $d$ value was classified as high.
Regarding the perceptions related to the maternal practices, it was noted that there were statistically significant differences between the clinical and nonclinical groups. The clinical group reported a strong presence of negative practices when compared to the nonclinical group, and in these comparisons the effect size ranged from 0.61 (physical abuse) to 0.89 (neglect), being considered high. The nonclinical group reported a strong 
presence of positive practices in relation to the clinical group, and for these differences the effect size for positive monitoring was 0.47 and 0.33 for moral behavior, classified as medium.

\section{Predictive Analyses}

Table 3 presents the estimates of two adjusted models for the $\operatorname{Exp}(B)$ of the independent variables that were predictive of behavioral problems.

In the first model, the binary logistic regression analysis with the Enter method resulted in a significant and adjusted model $\left(G^{2}(24)=106.461, p \leq 0.001 ; X^{2}\right.$ Wald (8) $\left.=4.991, p=0.759, R_{c s}^{2}=0.244 ; R_{N=}^{2} 0.505\right)$. It was noted in this model that the probability of having behavioral problems increased due to D2-difficulty in self-control and F3- frequency in civility. On the other hand, the odds decreased as a result of F6-frequency in social resourcefulness, D6-difficulty in social resourcefulness, physical abuse, neglect and inconsistent punishment.

Considering these results, it was chosen to construct a second more parsimonious model, including only the significant variables of the previous model: D2-difficulty in self-control, F3- frequency in civility,
F6-frequency in social resourcefulness, D6-difficulty in social resourcefulness, physical abuse, neglect and inconsistent punishment, using the Enter method. This second model was also statistically significant $\left(G^{2}(7)\right.$ $=68.823, p \leq 0.001 ; X_{\text {Wald }}^{2}(8)=2.668, p=0.953, R_{c s}^{2}$ $\left.=0.206, R_{N=}^{2} 0.310\right)$. The D2 variable - difficulty in self-control contributed to the increase in the likelihood of presenting behavioral problems of a clinical character, while F6-social resourcefulness, physical abuse and neglect contributed to decrease the ratio between being in the clinical group rather than the nonclinical group.

\section{Classification of the Models: Values of sensitivity and specificity}

For the first model, the correct classification of cases was $84.9 \%$, with the specificity being $57.9 \%$ and the sensitivity $92.1 \%$. For the second model, the correct classification of cases was $79.9 \%$, with the specificity being $93.9 \%$ and the sensitivity $34.3 \%$.

\section{Discussion}

Based on self-report measures applied with the adolescents, the present study sought to correlate,

Table 3.

Adjusted Models for the Exp(B) of the Independent Variables that were Predictive of Behavioral Problems

\begin{tabular}{lcccccccc}
\hline & & & & & & \multicolumn{2}{c}{$(95 \% \mathrm{CI})$} \\
\cline { 6 - 9 } & & $S E$ & Wald & $d f$ & $p$ & Exp (B) & Lower & Higher \\
\hline $\mathbf{1}^{\text {st }}$ Model & & & & & & & & \\
Independent variables & & & & & & & & \\
D2-Self control & 0.032 & 0.012 & 6.956 & 1 & 0.008 & 1.032 & 1.008 & 1.057 \\
F3-Civility & 0.017 & 0.008 & 4.503 & 1 & 0.034 & 1.018 & 1.001 & 1.034 \\
F6-Social resourcefulness & -0.030 & 0.012 & 6.702 & 1 & 0.010 & 0.970 & 0.948 & 0.993 \\
D6-Social resourcefulness & -0.036 & 0.012 & 9.841 & 1 & 0.002 & 0.964 & 0.942 & 0.986 \\
Physical Abuse & -0.014 & 0.006 & 6.198 & 1 & 0.013 & 0.986 & 0.975 & 0.997 \\
Neglect & -0.023 & 0.008 & 8.607 & 1 & 0.003 & 0.977 & 0.962 & 0.992 \\
Inconsistent punishment & -0.023 & 0.009 & 5.992 & 1 & 0.014 & 0.978 & 0.960 & 0.996 \\
\hline $2^{\text {nd }}$ Model & & & & & & & & \\
Independent variables & & & & & & & & \\
D2-Self control & 0.024 & 0.007 & 13.184 & 1 & 0.000 & 1.025 & 1.011 & 1.038 \\
F6-Social resourcefulness & -0.016 & 0.006 & 7.239 & 1 & 0.007 & 0.984 & 0.973 & 0.996 \\
Physical Abuse & -0.009 & 0.004 & 4.732 & 1 & 0.030 & 0.991 & 0.983 & 0.999 \\
Neglect & -0.017 & 0.006 & 9.352 & 1 & 0.002 & 0.983 & 0.972 & 0.994 \\
\hline
\end{tabular}

Note: D - difficulty; F - frequency. SE - Standard error; $d f=$ degree of freedom; CI = confidence interval. 
compare and identify the predictive value of a model for behavioral problems, including the following variables: parenting practices (family), social skills, social competence, academic performance, substance use (personal), age, and socioeconomic status (demographic).

In relation to the correlational data regarding maternal parenting practices, data from the present study identified statistically significant negative correlations in all practices (positive monitoring, moral behavior, physical abuse, neglect, negative monitoring, relaxed discipline and inconsistent punishment). These data also highlight data from the studies by Gomide (2014), Sabbag (2010) and Salvo (2010), which found that with more negative IEP indices, the behavioral problem scores were higher.

In general, the social skills in the frequency indicator (F1-Empathy, F2-Self-control, F3-Civility, F4-Assertiveness, F6-Social resourcefulness) and social competence obtained statistically significant negative correlations. These data are in agreement with some studies that also identified associations of fewer social skills and less social competence with more behavior problems (Del Prette et al., 2012; Durbag et al., 2010; Sabbag, 2010). Regarding the indicator of difficulty of social skills, the data from the present study identified statistically significant positive correlations between all the factors and behavior problems. These data also agree with, at least partially, the study by Del Prette et al. (2012) that identified that behavioral problems were positively correlated with difficulties in self-control, social resourcefulness and empathy.

Academic performance was negatively correlated with the behavior problems of the adolescents, which is also consistent with previous studies that showed that behavioral problems are associated with lower academic performance (Hossain, 2013; McLeod et al., 2012).

Considering the comparisons between the clinical and nonclinical groups, for the majority of the variables, the magnitude of the differences was medium, with the statistically significant ones, with higher means for the nonclinical groups in the frequency indicators for the social skills classes, being: total score; F1- selfcontrol; and F6- social resourcefulness. In the difficulty indicators these were: general score; D1- empathy; D2self-control; D3-civility; and D4- affective approach. These indicators show that the respondents from the clinical group reported having more difficulties in emitting these social skills. This data is, in part, related to data from the study by Campos (2014), which highlighted that adolescents with indicators of depression (internalizing) presented lower means in social skills compared to adolescents without indicators of depression. Regarding the perceptions about the maternal parenting practices, it was found that there were statistically significant differences between the clinical and nonclinical groups. The clinical group reported a higher presence of negative practices (physical abuse, neglect, relaxed discipline and inconsistent punishment) when compared to the nonclinical group, these being the comparisons with higher magnitudes of difference. The nonclinical group reported a greater presence of positive practices (positive monitoring and moral behavior) in relation to the clinical group, which is in line with the studies by Sabbag and Bolsoni-Silva (2011) and Sabbag (2010).

Using binary logistic regression with reference to data from the second model, which was more parsimonious, it was found that D2- difficulty in self-control contributed to increase the likelihood of behavioral problems; while F6-social resourcefulness and a low frequency of physical abuse and neglect contributed to decrease the odds ratio between being in the clinical group and the nonclinical group. The predictive model presented reasonable predictive abilities, with the correct classification of cases being $79.9 \%$, with high specificity and low sensitivity (Marôco, 2011).

The difficulty in self-control class contributed to increase the likelihood of behavioral problems in the adolescents. In the study by Campos et al. (2014), with a sample of adolescents with indicators of depression (internalizing), the self-control class, in the frequency indicator, appeared as a protection factor. When analyzing this class, its relevance was verified, since the difficulty in emitting self-control behaviors can signify a high response cost and poor learning of exposure and tolerance to feelings such as sadness, anger and frustration (Campos et al., 2014), which increases, probabilistically, the likelihood of entering risk situations, characteristic of adolescence.

The social skills related to the frequency indicator of social resourcefulness were identified as variables that decreased the chances of behavioral problems. These skills are included in a good communication repertoire (Del Prette \& Del Prette, 2009). Possibly, when adolescents have this repertoire the chances to solve problems, to feel satisfaction, well-being and relief and to have access to important information are increased.

The low frequency of the parenting practice of physical abuse was also identified as a variable that decreased the likelihood of the adolescent presenting 
behavioral problems, which is also in agreement with previous studies (Gomide, 2014; Toni \& Silvares, 2013). Possibly, parenting practices such as beating, spanking, burning and shaking the adolescent can function as a model for problem solving characteristic of low selfcontrol, favoring responses with aggressive function, as is the case of externalizing problems, which can produce, as a side effect, depressive/anxious behavior, as is the case of internalizing problems. Thus, the low frequency of these parenting practices can favor the good development of the adolescent.

The low frequency of the perception of the parenting practice of neglect also appeared as a variable that decreased the likelihood of behavioral problems of the adolescent and these data also match those obtained in other studies (Cassandra, 2010, Gomide, 2014, Mills et al., 2013). Gomide (2014) reported that the children of parents that present neglect practices have major behavioral deficits, or may even present reactions with an aggressive function to get their attention. Another consequence of parental neglect for the development of the child is the lack of learning about the risk of developing attachment bonds with strangers, which ultimately facilitates the development of delinquency (Gomide, 2014).

It is necessary to highlight some limitations of the study, for example due to the sample size it was not possible to perform specific analyses for internalizing and externalizing behavior problems, or analyses by gender. The predictive variables for each type of problem and also for the gender of the adolescents may be different, with it being possible for future studies to remedy this gap. Another limitation that requires analysis was taking the adolescents as the only source of data regarding the assessments of behavioral problems and the evaluation of the maternal parenting practices.

Within these limits, it is considered that the study contributed to a better understanding of which variables (family, personal and demographic) are important for the prediction of behavior problems, from the perspective of the adolescents. The large number of variables included in the model was consistent with the theoretical assumptions that behavioral problems are multidetermined (Milkman \& Wanderg, 2012), requiring different domains to be covered, as was carried out in this study. As a result of the present study, the importance of identifying the protective value of selfcontrol, social resourcefulness and of a low frequency of physical abuse and maternal neglect as conditions that minimize behavioral problems in adolescents was highlighted, which may be instrumental in preventive and treatment programs.

\section{References}

Achenbach, T. M., \& Rescorla, L. A. (2001). Manual for the ASEBA school-age forms \& profiles. Burlington, VT: University of Vermont, Research Center for Children, Youth, \& Families.

Aalsma, M. C., Liu, G. C., \& Wiehe, S. E. (2011). The role of perceive parent monitoring and support on urban child and adolescent problem behavior. Community Mental Health Journal, 47(1), 61-66. doi: 10.1007/s10597-009-9251-2.

Anzano, S. M., Rubio, J. M. L \& Sánchez, I. M. H. (2004). Peculiaridades metodológicas de lapsicología de lasalud. In J. M. L. Rubio, S. M. Anzano. S. B. Jimenez, A. B. Reganã \& I. M. H Sánchez (Eds). Psicología de la Salud y de la Calidade de Vida (1th ed, pp 97-130). Uoc: Barcelona.

Bolsoni-Silva, A. T., Loureiro, S. R., \& Marturano, E. M. (2014). Roteiro de Entrevista de Habilidades Sociais Educativas Parentais - Manual Técnico - RE-HSE-P. 1. ed. São Carlos: Suprema Gráfica e Editora Ltda, $120 \mathrm{p}$.

Campos, J. R., Del Prette, A. \& Del Prette, Z. A. P (2014). Depressão na adolescência: Habilidades sociais e variáveis sociodemográficas como fatores de risco/proteção. Estudos e Pesquisas em Psicologia, 14 (2), 408-428. Retirado de: http://www.redalyc.org/articulo.oa?id $=451844508003$

Campos, J. R. (2014). Avaliação das habilidades sociais e variáveis sociodemográficas de adolescentes com e sem indicadores de depressão. Tese de doutorado, Universidade Federal de São Carlos, São Carlos, SP.

Cassandra, S. (2010). Why do adolescents become involved with the child welfare system? Exploring risk factors that affect young adolescents. Children and Youth Services Review, 32(12), 1831-1836. doi. org/10.1016/j.childyouth. 2010.08.004

Colder, C. R., Scalco, M., Trucco, E. M., Read, J. P., Lengua, L. J., Wieczorek, W. F., \& Hawk Jr, L.W. (2013). Prospective associations of internalizing and externalizing problems and their co-occurrence with early adolescent substance use. Journal $A b$ normal Child Psychology, 41, 667-677. doi: 10.1007/ s10802-012-9701-0. 
De Micheli, D., \& Formigoni, M. L. O. S. (2000). Screening of drug use in a teen age Brazilian sample using the Drug Use Screening Inventory (DUSI). $A d$ dictive Behaviors, 25 (5), 683-91. doi.org/10.1016/ S0306-4603(00)00065-4

Del Prette, A., \& Del Prette, Z. A. P (2009). Inventário de habilidades sociais para adolescentes (IHSA-Del Prette): Manual de aplicação, apuração e aplicação. São Paulo: Casa do Psicólogo.

Del Prette, Z. A. P., \& Del Prette, A. (2012). Social skills and behavior analysis: Historical proximity and new issues. Perspectivas em Análise do Comportamento, 1(2), 104-115. Retrieved from: http://www.scielo.org.co/scielo. php?script $=$ sci_nlinks\&ref $=000116 \&$ pid $=$ S17944724201500010001000010\&lng $=\mathrm{en}$

Del Prette, Z. A. P., \& Del Prette, A. (2001). Psicologia das habilidades sociais: Terapia e educação. Petrópolis: Vozes.

Del Prette,Z. A. P., Rocha, M. M., Silvares, E. F. M., \& Del Prette, A. (2012). Social skills and psychological disorders. Universitas Psychologica, 11(3), 941-955. Retrieved from: http://www.producao.usp.br/ bitstream/handle/BDPI/41382/wos2012-2800. pdf?sequence $=1$

Durlak, J. A., Weissberg, R. P., \& Pachan., M. (2010). A meta-analysis of after-school programs that seek to promote personal and social skills in children and adolescents. American Journal of Community Psychology, 45, 294-309. doi: 10.1007/s10464-010-9300-6.

Gomide, P. I. C. (2014). Inventário de Estilos Parentais. Modelo Teórico: Manual de Aplicação, apuração e interpretação. Petrópolis: Vozes.

Goodman, A. (2010). Substance use and common child mental health problems: Examining longitudinal associations in a british sample. Addiction, 14841496. doi: 10.1111/j.1360-0443.2010.02981.x.

Havas, J, Bosma, H, Spreeuwenberg, C., \& Feron, F. J. (2010). Mental health problems of Dutch adolescents: The association with adolescents' and their parents' educational level. European Journal of Public Health, 20(3), 258-264. doi: 10.1093/eurpub/ ckp172.

Hossain, S. (2013). A study of determining the relationship between academic achievement and problem behavior of urban secondary school students in bangladesh. The International Journal of Social Sciences, 8(1), 001-010, ISSN: 2305-4557. Retrieved from: https://www.tijoss.com/8th\%20Volume/saira. pdf

Kirkcaldy, B. D., Siefen, G., Surall, D., \& Bischoff, R. J (2004). Predictors of drug and alcohol abuse among children and adolescents. Personality and Individual Differences,36, 247-265. doi: 10.1016/ S0191-8869(03)00082-5

Ma, J., Han, Y., Grogan-Kaylor, A., Delva., J., \& Castillo., M. (2012). Corporal punishment and youth externalizing behavior in Santiago, Chile. Child Abuse \& Neglect, 36(6), 481-90. doi: 10.1016/j. chiabu.2012.03.006

Marôco, J. (2011). Análise Estatística com o SPSS STATIS TICS. Editor: Report.

McLeod, J. D., Uemura, R, \& Rohrman, S. (2012). Adolescent mental health, behavior problems, and academic achievement. Journal of Health and Social Behavior, 53(4) 482 -497. doi: 10.1177/0022146512462888.

Mills-Koonce, W. R., Willoughby, M. T., Garrett-Peters, P., Wagner, N., Vernon-Feagans, L., \& The Family Life Project Key Investigators (2016). The interplay among socioeconomic status, household chaos, and parenting in the prediction of child conduct problems and callous-unemotional behaviors. Development and Psychopathology, 28, 757 771. doi:10.1017/S0954579416000298

Mills, R., Scott, J., Alati, R., O'Callaghan, M., Najman, J. M \& Strathearn, L (2013). Child maltreatment and adolescent mental health problems in a largebirth cohort. Child Abuse \&Neglect, 37(5), 292-302. doi: 10.1016/j.chiabu

Milkman, H. B. \& Wanderg, K. W (2012). Adolescent development and pathways to problem behavior. In: H. B. Milkman \& K. W. Wanderg (Orgs). Criminal conduct and substance abuse treatment for adolescents: Pathways to self-discovery and change. (pp 21-54). SAGE.

Perera, H. (2013). Childhood predictors of adult mental disorders: Implications for prevention. Journal of Psychiatry, 4, 1-2. doi: http://doi.org/10.4038/ sljpsyc.v4i1.5712

Rocha, M. M (2012). Evidências de validade do Inventário de Autoavaliação para Adolescentes (YSR/2001) para 
a população brasileira. Tese de Doutorado, Universidade de São Paulo, SP.

Sabbag, G. M. (2010). Análise das práticas e das habilidades sociais educativas maternas na interação com os filhos adolescentes. Dissertação de Mestrado, Universidade Estadual Júlio de Mesquista Filho, Unesp Bauru, SP.

Sabbag, G. M. \& Bolsoni-Silva, A. T. (2011). A relação das Habilidades Sociais educativas e das práticas educativas maternas com os problemas de comportamento em adolescentes. Estudos e Pesquisas em Psicologia, 11, 2, 423-441. Retirado de: http://www. revispsi.uerj.br/v11n2/artigos/html/v11n2a04. html

Sabbag, G. M., \& Bolsoni-Silva, A. T. (2015). Interações entre mães e adolescentes e os problemas de comportamento. Arquivos Brasileiros de Psicologia, 67(1), 68-83. Retirado de: http://pepsic.bvsalud.org/ pdf/arbp/v67n1/06.pdf

Salvo, C. G. De (2010). Práticas educativas parentais e comportamentos de proteção e risco à saúde na adolescência.
Tese de Doutorado. Universidade de São Paulo, São Paulo, SP.

Tarter, R. (1990). Evaluation and treatment of adolescent substance abuse: A decision tree method. American Journal of Drug and Alcohol Abuse, 16, 1-46. doi.org/10.3109/00952999009001570

Toni, C. G. S. \& Silvares, E. F.M. (2013). Práticas educativas parentais e comportamentos de saúde e risco na adolescência: Um modelo preditivo. Psicologia Argumento, 31(74), 457-471. Retirado de: http://www2.pucpr.br/reol/pb/index.php/ pa?dd1 $=12237 \& d d 99=$ view\&dd $98=$

World Health Organization (2012). Adolescent mental health: Mapping actions of nongovernmental organizations and other international development organizations. Genebra. Retrieved from: http://apps.who.int/iris/bitst ream/10665/44875/1/9789241503648_eng.pdf

Recebido em: 24/01/2018

Reformulado em: 18/05/2018

Aprovado em: 29/08/2018 
Sobre as autoras:

Josiane Rosa Campos, clinical psychologist, graduated in psychology from Universidade Estadual Paulista-UNESP Bauru, holds a Master's degree and PhD in Psychology from Universidade Federal de São Carlos (UFSCar) and Post $\mathrm{PhD}$ in Developmental Psychology from UNESP-Bauru.

ORCID: https://orcid.org/0000-0001-5825-1134

E-mail: josirosacampos@gmail.com

Alessandra Turini Bolsoni Silva, psychologist, holds a Master's degree in Special Education from Universidade Federal de São Carlos UFSCar, PhD in Psychology from Universidade de São Paulo, Post PhD at the Ribeirão Preto Medical School -Universidade de São Paulo, 'Free Professor' in Clinical Psychology at Universidade Estadual Paulista Júlio de Mesquita. Professor in Clinical Psychology at Universidade Estadual Paulista Júlio de Mesquita Filho.

ORCID: http://orcid.org/0000-0001-8091-9583

E-mail: bolsoni@fc.unesp.br

Marta Regina Gonçalves Correia Zanini, psychologist, holds a Master's degree in Developmental and Learning Psychology and a PhD in Psychology. She is currently a lecturer in Psychology at Centro Universitário das Faculdades Associadas de Ensino - UNIFAE, where she conducts research in the area of developmental psychology and children's mental health in learning contexts.

ORCID: http://orcid.org/0000-0003-4776-8917

E-mail:psico_marta@yahoo.com.br

Sonia Regina Loureiro, psychologist, holds a Master’s degree in Clinical Psychology from Universidade de São Paulo. Lecturer at the Ribeirão Preto Medical School/ USP, advisor at the Graduate Programs in Psychology - FFCLRP-USP and at the Graduate Programs in Mental Health - FMRP-USP. Develops research activities in assessment instruments and procedures in different psychosocial contexts. E-mail: srlourei@fmrp.usp.br

ORCID: http://orcid.org/0000-0001-9423-2897

E-mail: srlourei@fmrp.usp.br

Contato com as autoras:

Josiane Rosa Campos

INAC-Instituto de Análise do Comportamento de Ribeirão Preto

Rua Quintino Bocaiuva, 1344, Vila Seixas

Ribeirão Preto-SP, Brazil

CEP: 14015-160 